\title{
REFERÊNCIA:
}

PARANHOS da COSTA, M. J. R.; ANDRIOLO, A.; SIMPLÍ́CIO DE OLIVEIRA, J. F.; SCHMIDEK, W. R. Suckling and allosuckling in river buffalo calves and its relation with weight gain. Applied Animal Behaviour Science, v. 66, p. 1-10. 2000.

\section{SUCKLING AND ALLOSUCKLING IN RIVER BUFFALO CALVES AND ITS RELATION WITH WEIGHT GAIN}

\section{MATEUS J.R. PARANHOS DA COSTA ${ }^{\mathrm{a}, \mathrm{e}, *}$, ARTUR ANDRIOLO ${ }^{\mathrm{b}, \mathrm{e}}$, JOSÉ F. SIMPLÍ́CIO DE OLIVEIRA ${ }^{\mathrm{C}}$, WERNER R. SCHMIDEK ${ }^{\mathrm{D}}$}

\footnotetext{
${ }^{a}$ Departamento de Zootecnia, Faculdade de Ciências Agrárias e Veterinárias, Universidade EstadualPaulista, 14870-000, Jaboticabal, SP, Brazil

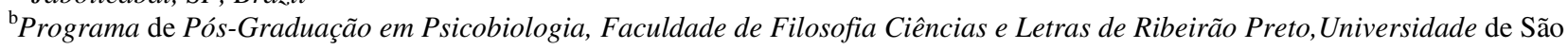
Paulo, Ribeirão Preto, SP, Brazil

${ }^{e}$ Estação Experimental de Zootecnia do Vale do Ribeira, Instituto de Zootecnia, Registro, SP, Brazil

${ }^{\mathrm{d}}$ Departamento de Fisiologia, Faculdade de Medicina de Ribeirão Preto, Universidade de São Paulo,Ribeirão Preto, SP, Brazil

${ }^{e}$ ETCO-Grupo de Estudos e Pesquisas em Etologia e Ecologia Animal, Brazil
}

Accepted 30 August 1999

The aim of the present study was to investigate if river buffalo calves (Bubalus bubalis) have equal access to all cows and if milk is thus equally available to all of them. We recorded suckling/allosuckling behaviour and weight gain (WG) of 29 calves (14 males and 15 females), with special consideration to their sex, birth order (B0) and age. Cows' nursing behaviour and milk production (MP) were also considered. While males tended to be bom earlier than females during this study, this was not the trend in the overall herd records. The cows' MP was not effected by the calves' sex. However, bull-calves presented greater mean WG, and mean times spent in individual filial (IF) and in communal nonfilial (CNF) suckling than heifer-calves, which showed greater communal filial (CF) suckling than the former during the first 4 months of life. The WG was associated with IF for bull-calves ( $r=0.680$ and 0.765 , respectively, for the periods from birth to 4th and 8th months of age), and to CNF for heifer-calves ( $r=0.628$, for the period from birth to 8th month). Results from multiple regression analysis showed independent effects of each suckling category on the calf WG, and such effects were variable according to the calf's sex. BO was negatively correlated to calves' $\mathrm{WG}$ (bull-calves: $r_{\mathrm{s}}=-0.873$ and -0.799 , from birth to 4th and 8th months, respectively; heifer-calves: $r_{\mathrm{s}}=-0.531$ from birth to 4th month). Specifically for bull-calves, there was a positive correlation between BO and MP ( $r_{\mathrm{s}}=0.528$ and 0.633 , from birth to 4th and 8th months of age, respectively). The correlation between BO and IF was negative in both sexes, indicating that calves that were born early had more opportunities to suckle individually from their mothers. For heifer-calves, BO was positively correlated with CF (two periods), and negatively with CNF (from birth to 8th month of age), suggesting that heifer-calves were most often accompanied by other calves during suckling when they were bom later. The data taken together indicate that sex and/or BO influenced decisively social interactions during suckling, promoting differential development among the calves. In animal husbandry, if a homogenous WG is desired, these factors have to be taken into consideration.

(C) 2000 Elsevier Science B.V. All rights reserved. 
Keywords: Bubalus bubalis; Nursing behaviour; Calf perfomance; Sex differences

\section{Introduction}

If we assume that the mother is the sole source of milk for her own offspring, then estimating her milk production (MP) would be a sufficient indicator of how much milk is available to her calf. This is a common assumption for cattle, resulting in a partial assessment of the matemal effects on calf performance (Fries and Albuquerque, 1998).

In water buffalo, this is not an adequate means to appraise matemal effects on calf performance, because it is common to see the calves, sometimes in group, suckling cows other than their own mother (Tulloch, 1979, 1988; Murphey et al., 1991; Paranhos da Costa et al., 1994; Murphey et al., 1995; Paranhos da Costa and Andriolo, 1998). This behaviour, identified as communal nursing by Murphey et al. (1991), was described as one adult female nursing groups of calves of other females. It seems a very costly pattem of alloparental care, since milk could be subtracted from her own calf and distributed to other calves.

A basic question about this behaviour related to milk availability and its effect on the development of calves would be: If all calves have equal access to cows and milk is thus equally available to all of them, one would expect no niajor differences among calves in weight gain (WG) due to milk ingestion.

The aim of the present investigation was to analyze this question assuming that milk ingestion of each animal was directly related to its suckling time and that its WG during the suckling period was also directly related to its milk ingestion. We recorded suckling and allosuckling behaviour and WG of the calves with special consideration to their sex and ages.

\section{Materiais and methods}

Data were collected at the Estação Experimental de Zootecnia do Vale do Ribeira (a

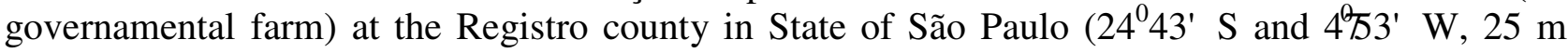
above sea level). We used a herd of river buffalo (Bubalus bubalis), predominantly Murrah phenotype, selected and handled for MP.

The routine daily handling of the animals began at $0600 \mathrm{~h}$, when the cows were hand-milked in the presence of their calves. During milking, the herdsmen allowed calves to suckle their own mothers for some minutes. After milking, all mother-offspring pairs were placed in a pen (measuring about $120 \mathrm{~m}^{2}$ ), where the calves might suckle their own mothers and / or any other cow. When the milking session was finished, at around $0800 \mathrm{~h}$, cows and calves were taken to the pasture where they remained until $1600 \mathrm{~h}$. After this and throughout the night, cows and calves were kept separated.

Our data were collected in 1993, during 3 consecutive days at the beginning of each month, starting in February with the birth of the first calves and ending in November with the imposed weaning. Twenty-nine calves were observed, eight males and two females were born in February, five males and four females in March, three females in April, one male and five females in May and one female in July. The animals were thus observed, respectively, for 10, 9, 8, 7 and 5 months. According to birth' s date of each calf, we define the calves' birth order (BO).

All animals were identified by numbers painted on their haunches. Mother and offspring received the same number. Observations were performed with the aid of binoculars and recorded on a portable cassette recorder. All animals were in sight all the time. Observations were direct and continuous between 1000 and $1600 \mathrm{~h}$. Using the behaviour sampling technique (Martin and Bateson, 1986), we recorded the time of beginning and ending of each occurrence of suckling behaviour, as well as the identification of the involved animals. Suckling behaviour was 
considered to occur each time a calf succeeded in getting a teat into its rnouth for any detectable period of time.

Suckling behaviour was classified into four categories: (a) individual filial suckling (IF): when a calf alone was suckling in its own mother; (b) communal filial (CF) suckling, comprising $\mathrm{CF}$ when a calf was suckling in his / her own mother with a group of calves, and communal nonfilial (CNF) when a calf was suckling another cow together with his/her own calf and, eventually, other calves; (c) nonfilial suckling (NF) when a calf, alone or in group, was suckling a cow while her own calf was not present. We also consider the time spent by the cows nursing their own calves, alone (which represented the same value reported to IF) or in group (GF), and other calves than their own (ONF).

All the calves were weighed on birth and every 30 days after until weaning. At the same time intervals, MP was measured by weighing the milk produced in the morning by one single manual milking after complete emptying of the udder.

\section{2.l. Data analysis}

All data were refered to the age of the calf at the time of the observation. Data from suckling behaviour (IF, CF, CNF, NF, GF, and ONF), representing the total time spent in each category from 1000 to $1600 \mathrm{~h}$, were transformed by $\sqrt{x}+0.5$, in order to meet the requirements of normally distributed data.

By practical implications, the statistical analyses were carried out using two groups of data, considering two periods of calves' life: (1) from birth to 4th month of age, wherthe milk is the main source of nutrients to calves; (2) from birth to 8th month of age, since water buffalo calves are usually weaned at this age.

Inter-sexual comparisons of WG, MP, IF, CF, CNF, and NF were perforrned by Student' \$test.

Pearson' sor-relation coefficients $(r)$ were estimated for individual values of WG and the corresponding mean times spent by calves in each type of suckling behaviour and MP of their mothers. The same approach was used in considering the cows' MP and their time spent nursing. In order lo detail the relationships between the WG $(y)$ and the suckling behaviour $\left(x_{n}\right)$, we performed a multiple regression analysis (Iles, 1993).

In order lo analyze the relationships between the $\mathrm{BO}$ of calves and their $\mathrm{WG}$ and behavioural suckling performance, Spearinan' $\mathrm{s}$ rank correlation coefficients $r_{\mathrm{s}}$ ) were estimated using non-transformed data (Siegel, 1956).

\section{Results}

Most births (97\%) occurred from February lo May, and 68\% of calves which were born during February and March were bull-calves.

Mean values of WG of bull- and heifer-calves and MP of their mothers, for both periods, from birth to 4th and 8th months of age, respectively, are shown in Table 1. Buil-calves' mean WG was significantly greater than that of heifer-calves in both periods. However, the sex of the calves did not have a statistically significant effect on matemal MP.

Bull-calves also presented greater IF and CNF means than heifer-calves in both periods $(\mathrm{P}<0.05)$, however, the former showed a lower $\mathrm{CF}$ mean from birth to 4th month of age. Conversely, no significant differences were found for the other categories of suckling (Fig. 1).

Correlation of individual values of cows' MP with the time spent by them nursing its own calf, alone (IF) or in group (GF), and other calves than its own (ONF), besides with their calf s WG, are presented in Table 2. As shown, there were significant figures only for bull-calves; their 
mothers' MP negatively correlated with their WG and IF, and positively with GF in the first suckling period.

The coefficients of correlation between WG and the time spent in each suckling category (IF, CF, CNF, and NF) are presentes in Table 3 for both sexes.

Table 1. Mean values \pm standard deviation of river buffalo calves' WG ( $\mathrm{kg} /$ day) and their mother MP ( $\mathrm{kg} /$ day) from birth to $4^{\text {th }}$ and $8^{\text {th }}$ months of age, respectively

\begin{tabular}{lcccc}
\hline & \multicolumn{2}{c}{ From birth to $4^{\text {th }}$ months of age } & \multicolumn{2}{c}{ From birth to $8^{\text {th }}$ months of age } \\
\cline { 2 - 5 } & Males $(\mathrm{N}=14)$ & Females $(\mathrm{N}=15)$ & Males $(\mathrm{N}=14)$ & Females $(\mathrm{N}=15)$ \\
\hline WG & $0.49 \pm 0.13^{*}$ & $0.39 \pm 0.11$ & $0.43 \pm 0.09^{*}$ & $0.33 \pm 0.08$ \\
MP & $4.18 \pm 0.60$ & $4.56 \pm 1.01$ & $3.46 \pm 0.61$ & $3.77 \pm 0.83$ \\
\hline
\end{tabular}

* significant difference between males and females at $\mathrm{P}<0.05$

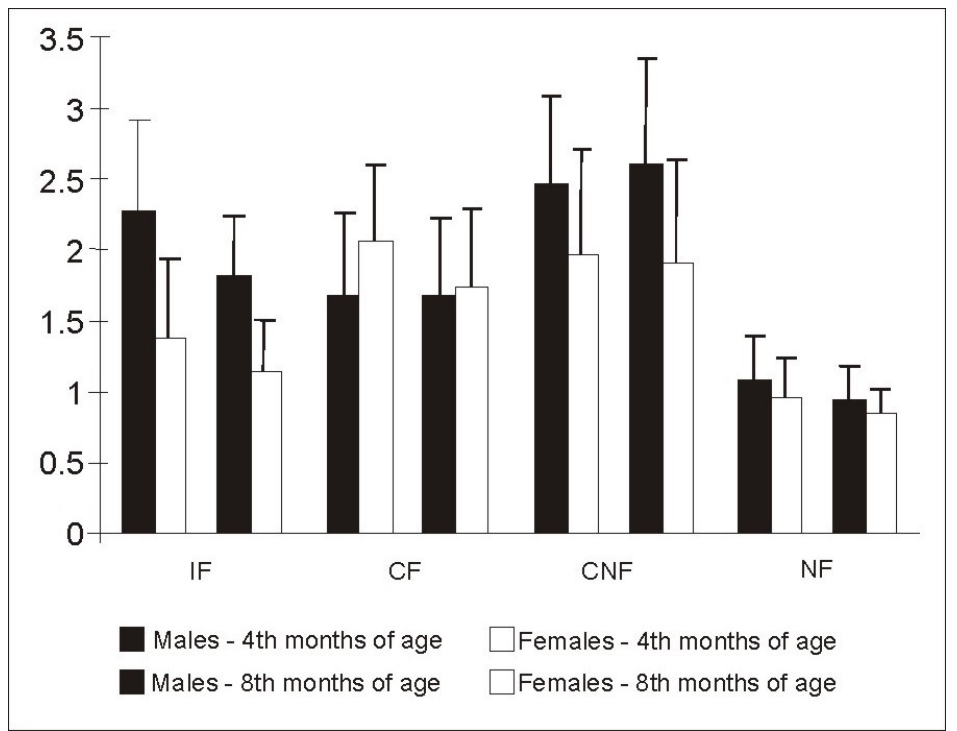

Figure 1. Mean values and standard deviations of the times spent by male and female river buffalo calves during the first 4 and 8 months of their lives in each type of suckling behavior; where: IF and $\mathrm{CF}=$ suckling their own mother alone or in group, respectively; $\mathrm{CNF}$ and $\mathrm{NF}=$ suckling another cow, respectively, together with or without her own calf, and eventually, other calves; * significant differences between male and female calves at $\mathrm{P}<0.05$.

As seen in Table 3, IF was the caregory of suckling behaviour most associated lo the bull-calves' WG. Although the relationship of WG with NF, for both periods and with

Table 2. Coefficients of correlation of MP with calves' WG and the time spent by cow nursing its own calf - alone (IF) or in group (GF), and other calves than its own (ONF), for both sexes of river buffalo calves from birth to 4 th and to 8 th months of age, respectively

\begin{tabular}{llcccc}
\hline & \multicolumn{2}{c}{ MP from } & \multirow{2}{*}{ Calves WG } & \multicolumn{3}{c}{ Nursing category } \\
\cline { 4 - 5 } $\begin{array}{l}\text { Males } \\
(\mathrm{N}=14)\end{array}$ & $\begin{array}{l}\text { birth to 4 } \\
\text { months of age }\end{array}$ & $-0.663(\mathrm{P}=0.010)$ & $-0.700(\mathrm{P}=0.005)$ & $0.582(\mathrm{P}=0.029)$ & $0.250(\mathrm{P}=0.388)$ \\
& $\begin{array}{l}\text { birth to 8th } \\
\text { months of age }\end{array}$ & $-0.527(\mathrm{P}=0.053)$ & $-0.558(\mathrm{P}=0.038)$ & $0.331(\mathrm{P}=0.248)$ & $0.147(\mathrm{P}=0.616)$ \\
Females & $\begin{array}{l}\text { birth to 4 } \\
\text { months of age }\end{array}$ & $0.043(\mathrm{P}=0.879)$ & $-0.079(\mathrm{P}=0.779)$ & $0.076(\mathrm{P}=0.788)$ & $-0.016(\mathrm{P}=0.954)$ \\
& $\begin{array}{l}\mathrm{N}=15) \\
\text { birth to 8th } \\
\text { months of age }\end{array}$ & $0.074(\mathrm{P}=0.793)$ & $-0.111(\mathrm{P}=0.694)$ & $0.293(\mathrm{P}=0.289)$ & $-0.078(\mathrm{P}=0.783)$ \\
\hline
\end{tabular}


Table 3. Coefficients of correlation between $\mathrm{WG}$ and the time spent in each suckling category (IF, CF, CNF, and $\mathrm{NF}$, as described in the text), for both sexes of river buffalo calves from birth to 4th and to 8th months of age, respectively.

\begin{tabular}{|c|c|c|c|c|c|}
\hline & \multirow{2}{*}{$\begin{array}{l}\text { Calves } \\
\text { WG from }\end{array}$} & \multicolumn{4}{|c|}{ Suckling category } \\
\hline & & IF & $\mathrm{CF}$ & $\mathrm{CNF}$ & NF \\
\hline \multirow{2}{*}{$\begin{array}{l}\text { Males } \\
(\mathrm{N}=14)\end{array}$} & birth to $4^{\text {th }}$ & $0.689(\mathrm{P}=0.006)$ & $-0.258(\mathrm{P}=0.372)$ & $-0.032(\mathrm{P}=0.898)$ & $0.466(\mathrm{P}=0.093)$ \\
\hline & $\begin{array}{l}\text { months of age } \\
\text { birth to } 8^{\text {th }} \\
\text { montbs of age }\end{array}$ & $0.765(\mathrm{P}=0.001)$ & $-0.292(P=0.312)$ & $0.519(\mathrm{P}=0.057)$ & $0.418(P=0.137)$ \\
\hline \multirow{2}{*}{$\begin{array}{l}\text { Females } \\
(\mathrm{N}=15)\end{array}$} & birth to $4^{\text {th }}$ & $0.308(\mathrm{P}=0.263)$ & $-0.467(P=0.079)$ & $0.502(\mathrm{P}=0.057)$ & $0.134(\mathrm{P}=0.636)$ \\
\hline & $\begin{array}{l}\text { birth to 8th } \\
\text { months of age }\end{array}$ & $0.293(\mathrm{P}=0.289)$ & $-0.134(P=0.632)$ & $0.628(\mathrm{P}=0.012)$ & $0.293(\mathrm{P}=0.289)$ \\
\hline
\end{tabular}

$\mathrm{CNF}$, from birth to 8th month of age, did not get statistical significance, after a visual inspection of residual plots, we decided to consider them together with IF in a multivariate regression analysis resulting in the following equations:

WG4th $=0.118+0.121 \mathrm{IF}+0.0912 \mathrm{NF}\left(\mathrm{r}^{2}=0.518, P=0.018\right)$

$\mathrm{WG} 8 \mathrm{th}=0.072+0.142 \mathrm{IF}+0.0077 \mathrm{NF}+0.0338 \mathrm{CNF}\left(r^{2}=0.658, \mathrm{P}=0.011\right)$.

Heifer-calves' WG were correlated positively and significantly with CNF only. However, considering a graphical analysis, we also took in account the linear CF effect on WG from birth lo 4th month of age, as shown below:

WG4th $=0.245-0.0749 \mathrm{CF}+0.061 \mathrm{CNF}\left(r^{2}=0.379, \mathrm{P}=0.057\right)$;

WG 8 th $=0.202+0.0687 \mathrm{CNF}\left(r^{2}=0.394, \mathrm{P}=0.012\right)$.

Bull-calves' WG, in both periods of life, were negatively correlated with their $\mathrm{BO} r_{\mathrm{s}}=-$ 0.873 and $r_{s}=-0.799$, both $\left.\mathrm{P}<0.001\right)$. For heifer-calves, there were also similar negative correlation, but statistically significant only for the first period $\left(r_{s}=-0.531, P<0.05\right)$. The Spearman' s rank correlation coefficients between bull-calves' $\mathrm{BO}$ and the corresponding MP by their mothers were: $r_{s}=0.528(\mathrm{P}=0.053)$ and $r_{s}=0.633(P=0.015)$, from birth to 4th and 8th months of age, respectively. Equivalent correlation for heifer-calves were lower and not statistically significant $\left(r_{s}=0.213\right.$ and $r_{s}=0.167, P>0.05$, respectively).

Correlation betwen $\mathrm{BO}$ and IF were negative and elevated for both sexes in both periods: bull-calves: $r_{s}=-0.670(\mathrm{P}<0.001)$ and $r_{s}=-0.714(\mathrm{P}=0.001)$; and heifer-calves: $r_{s}=-0.543$ $(P=0.043)$ and $r_{s}=-0.455(P=0.089)$, respectively, from birth lo 4 th and 8 th months of age. For heifer-calves, BO was also positively correlated with $\mathrm{CF}$ in both periods $\left(r_{s}=0.618, P=0.014\right.$ and $r_{s}=0.518, P=0.048$, respectively), and negatively with CNF from birth to 8 th month of age ( $\left.r_{s}=-0.546, P=0.035\right)$. 


\section{Discussion}

According to the present results, the suckling behaviour of the water buffalo calves had an important effect on their $\mathrm{WG}$, and the relationships between these characteristics (suckling behaviour and WG) were dependent of the calves' sex and/or BO.

As reported, bull-calves showed higher WG than heifer-calves. These results support those presented by many other researchers (Baliero et al., 1994; Oliveira et al., 1994; Peeva and Vankov, 1994), but contradict some others (Sukri et al., 1994; Zava, 1994). Several factors could cause this differential growth rate, among them, we have to consider the potential effect of BO, since in our herd, just in 1993, bull-calves were born earlier than heifer-calves.

The possibility of higher maternal investment in male rather than in female offspring, as discussed by Redondo et al. (1992), was investigated. We did not find significant differences between the MP in cows mothering bull- or heifer-calves. Instead, in both periods of calves life, the MP of cows mothering males was negatively correlated with WG and IF suckling time of their offspring, and, more, it was positively correlated with the time spent by these cows nursing their own calves in group (GF) during the first period of calves life. For heifer-calves, we did not find any significant correlation among these traits.

We do not know precisely which factors were involved in the sex WG differentiation. However, it seems to be clearly related to the sexual differentiation in calves' sucklingbehaviour.

When we investigated the amount of time spent in each suckling category as a predictor variable for the water buffalo WG, we found, as shown in Eqs. (I)-(4), that the bull-calves' WG was strongly influenced by IF suckling time for bull-calves, whereas for heifer-calves CNF suckling time was more important. These results suggest that bull-calves were more affected by their mothers' milk competition than heifer-calves, probably because they were under a differential allosuckling pressure, which was underlaid by their social behaviour and their mothers' milk availability. Thus, in spite of the lack of direct evidence of higher maternal investment in male offspring, we cannot discount the hypothesis of differential maternal investment according to the calves' sex.

On the other hand, it would be expected, as shown by Tiplady (1990) for Ovibos moschatus, that calves whose mothers showed frequent allosuckling would have a lower growth rate. Conversely, one would also expect that by avoiding collective suckling, cows would also exclude their own calves from suckling and thus resulting in their lower growth rate (Andriolo et al., 1994).

The first hypothesis was supported by the results presented by Murphey et al. (1995), since they found a negative correlation $(r=-0.498, p<0.05)$ between acceptance of other calves and growth rate of their own calf. This is in some extent supported by the present results, since there was a tendeney towards the $\mathrm{CF}$ suckling to present a negative relationship only with the heifercalves WG in their first period of life. Nevertheless, in spite of the long CNF suckling time spent by the bull-calves, their WG was more influenced by IF, whereas NF and CNF resulted only in a minor effect on it, as characterized in Eqs. (3) and (4). This is a suggestive finding, since the increase in suckling time seems to be not always associated with an increased volume of ingested milk.

We do not know how much time the water buffalo calves spent suckling without milk ingestion, but we suggest that could be a considerable length of time, perhaps similar to that found by Lidfors et al. (1994) in cattle, presenting between $39.3 \%$ and $50 \%$ of the total suckling bout duration as non-nutritive suckling.

Non-nutritive suckling and its underlying factors were well discussed by de Passillé and Rushen (1997). In our study, most of the non-nutritive suckling probably resulted from the cows retaining milk when alien calves attempted to suckle. This reaction probably also resulted in the exclusion of their own offspring during CF suckling, and thus could be a determinant factor in the 
lower growth rate presentes by heifer-calves. The behaviour of cows during these attempts were quite variable, sorne of them showed very intense rejection whereas others reacted less intensely (Paranhos da Costa and Andriolo, 1998; Paranhos da Costa et al., 1994).

The strong association between WG and IF in bull-calves suggested that calves obtain proportionally more milk by suckling their rnother alone than in other types of suckling. This was most likely because they had greater chances to suckle alone with their own mothers, since heifercalves were born later and had to compete with bull-calves. The heifer-calves were more dependent upon the communal suckling.

WG of calves during the first months of life is probably dependent on the amount of ingested milk, which may be expected to be independent of the type of suckling. Thus, one would

expect that calves would tend to compensate any reduction in their own mothers' MP by suckling other cows. According to our results, that expectation was valid only for bull-calves, and even in this case it was not completely clear cut, since their CF suckling time did not present any relationship with their WG.

Hypothetically, there may be a reciprocity among buffalo cows showing allonursing, rendering such a behavioural response beneficial to the group. However, such a hypothesis is in conflict with Murphey et al. (1993, 1995) who studied this species in the same farm as this study, but at a different time and with different individuals and showed no evidence of reciprocity among water buffalo cows in terms of allonursing.

The possibility that by nursing other calves the cows would be increasing their biological fitness (by increasing their "inclusive fitness") or any similar hypothesis has also to be discounted since Murphey et al. $(1991,1995)$ showed no preferential nursing for closely related calves.

As regards the issue of animal husbandry, it is important to note that there was a negative correlation between filial nursing (IF) and BO. Calves bom later in the period had to stand a strong competition for the milk of their own mothers, with elder and thus sturdier calves. Taking into consideration also the results of Souza et al. (1994), who found a positive correlation between age of the calf and access to other cows for allonursing ( $r=0.473, \mathrm{p}<0.01$ ), we suggest the usefulness of separating calves into different groups, according to their ages. Additionally, it would be useful to identify cows that are prone to allonursing in order to control more effectively the development of their own calves, and also in order to identify potential nurses for orphan calves.

\section{Acknowledgements}

We are grateful to adininistrators, Dr. Pietro S. Baruselli and Sebastião B. da Costa, and to husbandrymen Manoel da Silva Filho, Jesus M. de Souza, Antonio M. Lopes Neto, and Isael A. da Silva, all from the Estação de Zootecnia do Vale do Ribeira, for their help during the collection of the data. We are also grateful to Roberto C. de Souza and Humberto Giusti for their help in collecting and processing the data and to R.H. Bradshaw and M.J. Cork for their suggestions and revision of the English text. This research had financial supports from the Fundunesp (grant no. 121/93), and from Fapesp (grant no. 93/0127-5). This article was revised while the first author was a visiting scholar at the Animal Welfare and Human-Animal Interactions Group, Department of Clinical Veterinary Medicine, University of Cambridge, UK, sponsored by Fapesp (grant no. 97/40356-9). 


\section{References}

ANDRIOLO, A., SCHMIDEK, W.R., PARANHOS DA COSTA, M.J.R., 1994. Preferential nursing of the offspring in water buffalo (Bubalus bubalis) female. Congresso Nacional y Latinoamericamo de Etología, Vth, Valencia, España, Proceedings, p. 24, Abstract.

BALIERO, J.C.C., BALIERO, E.S., LISEU, L.C., 1994. Environmental effects en birth weight of the buffaloes Murrah, Jaffarabadi and Mediterranean. World Buffalo Congress, IVth, São Paulo. Brazil, Proceedings, Vol. 2, pp. 21-23.

de Passillé, A.M., Rushen, J., 1997. Motivational and physiological analysis of the causes and consequences of non-nutritive sucking by calves. Appl. Anim. Behav. Sci. 53, 15-31.

FRIES, L.A., ALBUQUERQUE, L.G., 1998. Pressuposições e restrições dos modelos animais com efeitos matemos em gado de corte. In: Paranhos da Costa, M.J.R., Cromberg, V. (Eds.), Comportarnento Materno em Mamíferos (Bases Teóricas e Aplicações aos Ruminantes Domésticos). Sociedade Brasileira de Etologia, São Paulo, pp. 179-214.

LLES, T.C., 1993. Multiple regression. In: Fry, J.C. (Ed.), Biological Data Analysis. IRL Press, Oxford, pp. 127-172.

LIDFORS, L.M., JENSEN, P., ALGERS, B., 1994. Suckling in free-ranging heef cattle - temporal patteming of suckling bouts and effeets of age and sex. Ethology 98, 321-332.

MARTIN, P., BATESON, P., 1986. Measuring Behaviour: An Introductory Guide. Cambridge Univ. Press, Cambridge.

MURPHEY, R.M., PARANHOS DA COSTA, M.J.R., LIMA, L.0.S., DUARTE, F.A.M., 1991. Communal suckling in water buffalo (Bubalus bubalis). Appl. Anim. Behav. Sci. 28, 341-352.

MURPHEY, R.M., PENEDO, M.C.T., PARANHOS DA COSTA, M.J.R., GOMES DA SILVA, R., SOUZA, R.C., 1993. Microsatellite DNA analysis in testing relationships between kinship and communal nursing in water buffalo (Bubalius bubalis) Behav. Genet. 23 (6), 559, abstract.

MURPHEY, R.M., PARANHOS DA COSTA, M.J.R., SILVA, R.G., SOUZA, R.C., 1995. Allonursing in river buffalo, Bubalus bubalis: nepotism, incompetence, or thievery? Anim. Behav. 49, 1611-1616.

OLIVEIRA, J.F.S., BARUSELli, P.S., MATTOS, J.C.A., CAMPOS, B.E.S., JORGE, A.M., 1994. Performance of Murrah buffaloes in Ribeira Valley - São Paulo, Brazil. World Buffalo Congress, IVth, São Paulo, Brazil, Proceedings, Vol. 2, pp. 43-45.

PARANHOS DA COSTA, M.J.R., ANDRIOLO, A., 1998. Amamentação e alo-amamentação em búfalos (Bubalus bubalis). In: Paranhos da Costa, M.J.R., Cromberg, V.U. (Eds.), Comportamento Materno em Mamíferos (Bases Teóricas e Aplicações aos Ruminantes Domésticos). Sociedade Brasileira de Etologia, São Paulo, pp. 247-262.

PARANHOS DA COSTA, M.J.R., SILVA, R.G., MURPHEY, R.M., SOUZA, R.C., 1994. Individual differences and behavioural factors affecting the suckling time in buffalo-calves on range. World Buffalo Congress, IVth, São Paulo, Brazil, Proceedings, Vol. 2, pp. 33-35.

PEEVA, T., VANKOV, K., 1994. The effect of some genetic and non-genetic factors on the body weight of huffalo calves. World Buffalo Congress, IVth, São Paulo, Brazil, Proceedings, Vol. 3, pp. 381-383.

REDONDO, T., GOMENDIO, M., MEDINA, R., 1992. Sex-biased parent-offspring conflict. Behaviour 123, 3-4.

SIEGEL, P., 1956. Non-parametric Statistics for the Behavioral Science. MacGraw-HiR, New York.

SOUZA, R.C., PARANHOS DA COSTA, M.J.R., MURPHEY, R.M., 1994. Efíciência de bezerros bubalinos no acesso a amamentação: efeitos do sexo, peso e idade dos bezerros. Anais de Etologia 12, 150, Resumo. 
SUKRI, M.I., NORDIN, Y., ABDULLAH SANI, R., 1994. Comparative growth perfomance of swarnp buffalo calves under semi-intensive and open pasture systems in Malaysia. World Buffalo Congress, IVth, São Paulo, Brazil, Proceedings, Vol. 2, pp. 79-81.

TIPLADY, B.A., 1990. Multiple nursing in free-living Muskoxen, Ovibos moschatus. Can. FieldNat. 104 (3), 450-454.

TULLOCH, D.G., 1979. The water buffalo, Bubalus bubalis, in Australia: reproductive and parent-offspring behaviour. Aust. Wildl. Res. 6, 265-287.

TULLOCH, D.G., 1988. Parent-offspring behaviour in feral water buffaloes in Australia. World Buffalo Congress, IInd, New Delhi, India, Proceedings, pp. 165-171.

ZAVA, M., 1994. Pre- and post-weaning weight gain control in humid sub-tropic natural pastures with Mediterranean, Murrah and Jaffarabadi buffaloes. World Buffalo Congress, IVth. São Paulo, Brazil, Proceedings, Vol. 2, pp. 95-97. 